ISSN: 2302-8556

E-Jurnal Akuntansi Universitas Udayana

Vol.24.2.Agustus (2018): 1164-1189

DOI: https://doi.org/10.24843/EJA.2018.v24.i02.p13

\title{
Pengaruh Tingkat Efisiensi, Risiko Kredit, dan Tingkat Penyaluran Kredit pada Profitabilitas
}

\author{
Ni Putu Intan Puspita Dewi ${ }^{1}$ \\ Dodik Ariyanto ${ }^{2}$
}

${ }^{1}$ Fakultas Ekonomi dan Bisnis Universitas Udayana (Unud), Bali, Indonesia
email: intanpuspita816@gmail.com_/ telp: +6281 239 291356
${ }^{2}$ Fakultas Ekonomi dan Bisnis Universitas Udayana (Unud), Bali, Indonesia

\begin{abstract}
ABSTRAK
Profitabilitas merupakan hal yang sangat penting diperlukan olehperusahaan untuk menjamin apakah keuntungan yang ditargetkan dalam beberapa periode telah tercapai. Profitabilitas mencerminkan kinerja yang baik dari perusahaan. Tingkat profitabilitas tercermin dari laba perusahaan. Bank perlu menjaga profitabilitas yang tinggi, prospek usaha yang berkembang, dan membagikan dividen dengan baik agar kinerjanya dinilai bagus. Penelitian ini bertujuan untuk mengetahui apakah tingkat efisiensi (BOPO), risiko kredit (NPL), dan tingkat penyaluran kredit (LDR) berpengaruh pada profitabilitas (ROA) pada perusahaan perbankan swasta di Bursa Efek Indonesia 2014-2016. Penelitian ini dilakukan pada perusahaan perbankan swasta yang terdaftar di Buersa Efek Indonesia 2014-2016. Jumlah sampel yang diambil sebanyak 34 perusahaan, dengan metode purposive sampling. Teknik analisis penelitian ini menggunakan analisis regresi linear berganda. Hasil penelitian ini menunjukkan bahwa tingkat penyaluran kredit berpengaruh positif terhadap profitabilitas. Kemudian tingkat efisiensi dan risiko kredit berpengaruh negatif terhadap profitabilitas.
\end{abstract}

Kata kunci: Tingkat Efisiensi, Risiko Kredit, Tingkat Penyaluran Kredit, Profitabilitas.

\begin{abstract}
Profitability is a very important thing required by the company to ensure whether the targeted profit in some period has been achieved. Profitability reflects the good performance of the company. The level of profitability is reflected in the company's earnings. Banks need to maintain high profitability, emerging business prospects, and distribute dividends well for good performance. The purpose of this study is whether BOPO, NPL, and LDR effect on profitability (ROA) at private banking companies in Indonesia Stock Exchange 2014-2016. This research was conducted at private banking companies registered in Indonesia Stock Exchange 2014-2016. The number of samples taken as many as 34 companies, with purposive sampling method. Analysis technique of this research use multiple linear regression analysis. The results of this study indicate that the level of credit disbursement has a positive effect on profitability. Then the level of efficiency and credit risk negatively affect profitability.
\end{abstract}

Keywords: NonPerforming Loan, Loan to Deposit Ratio, Profitability, BOPO, Bank. 


\section{PENDAHULUAN}

Profitabilitas merupakan hal yang sangat penting untuk diperhatikan perusahaan untuk menjamin apakah keuntungan yang ditargetkan dalam beberapa periode telah tercapai. Dalam perusahaan profitabilitas dapat digunakan sebagai acuan dari besarnya tingkat efisiensi perusahaan dalam mengatasi risiko keuangan (George dan Ouma, 2013). Besarnya tingkat profitabilitas dapat menggambarkan kinerja perusahaan yang baik, artinya perusahaan sudah berjalan secara efektif dan efisien, maka perusahaan dapat memperluas usahanya. Tingkat profitabilitas tercermin dari laba perusahaan. Keuntungan perusahaan adalah sebagai hal penting untuk keberlangsungan perusahaan dan bisa berperan dalam menarik modal dari luar yang dapat digunakan dalam pencapaian target investasi (Olalekan dan Adeyinka, 2013).

Berdasarkan Undang-Undang Republik Indonesia Nomor 10 Tahun 1998 tentang Perbankan, perbankan adalah segala sesuatu yang menyangkut tentang bank, mencakup kelembagaan, kegiatan usaha, serta cara dan proses dalam melaksanakan kegiatan usahanya. Sedangkan, bank merupakan badan usaha yang menghimpun dana dari masyarakat dalam bentuk simpanan dan menyalurkannya kembali pada masyarakat dalam bentuk kredit dan atau bentuk-bentuk lainnya untuk meningkatkan taraf hidup masyarakyat. Bank memberikan kontribusi besar terhadap perekonomian suatu negara. Profit pada perbankan memiliki kesamaan dengan bisnis lainnya, dimana hasil didapatkan dengan memaksimalkan pendapatan dan mengefisienkan biaya- biaya. Bank adalah tulang punggung semua industri, karena setiap transaksi 
ISSN: 2302-8556

E-Jurnal Akuntansi Universitas Udayana Vol.24.2.Agustus (2018): 1164-1189

dimana uang itu dilibatkan, bank merupakan pilar utama dana (Islam, et al., 2013). Salah satu aspek dasar untuk penilaian dan pengukuran terhadap kemampuan perbankan dalam menjalankan fungsinya, yaitu menghimpun serta mengelola dana dari masyarakat (Fathoni, 2017). Pengelolaan dana pada bank bertujuan untuk mewujudkan keuntungan atau profitabilitas, sebagai syarat kritis untuk menjalankan bisnis apapun (Menicucci dan Paolucci, 2016). Tanpa adanya keuntungan (profit), maka sangat sulit bagi perbankan untuk menarik modal dari luar. Pihak kreditur, pemilik perusahaan, dan pihak manajemen sangat berusaha untuk meningkatkan profitabilitas karena sangat penting bagi kelangsungan dan masa depan perusahaan.

Kepercayaan masyarakat merupakan hal penting dalam dalam menjalankan bisnis perbankan terutama lembaga Bank Umum. Ketatnya persaingan bank mengharuskan bank perlu meningkatkan kinerjanya dalam menarik investor. Sebelum investor mengambil keputusan untuk menginvestasikan dananya di bank maka investor membutuhkan informasi mengenai kinerja perusahaan. Investor memerlukan informasi yang dapat dimengerti, handal, dan relevan, maka dapat digunakan dalam menilai posisi keuangan dan kinerja bank yang dapat berguna dalam pengambilan keputusan ekonomi (Standar Akuntansi Keuangan, 2004).

Untuk mendapatkan kepercayaan, bank harus bekerja keras untuk dapat menarik investor dimana setiap calon investor yang akan melakukan investasinya pasti akan melihat profitabilitas dari bank tersebut. Profitabilitas merupakan kemampuan bank untuk menghasilkan atau memperoleh laba secara efektif dan efisien. Profitabilitas dapat dijadikan cerminan bahwa bank sudah memiliki 
kemampuan yang baik, artinya bank sudah beroperasi dengan efisien dan dapat memperluas usahanya. Bank perlu menjaga profitabilitas yang tinggi, prospek usaha yang berkembang, dan membagikan dividen dengan baik agar kinerjanya dinilai bagus.

Pengukuran profitabilitas pada penelitian ini menggunakan Return On Asset (ROA) karena ROA dapat memperhitungkan kemampuan manajemen bank dalam memperoleh laba secara keseluruhan. ROA menggambarkan efektifitas manajemen bank dalam mengelola asetnya untuk menghasilkan keuntungan (Dietrich dan Wanzenried, 2009). Apabila ROA meningkat berarti profitabilitas perusahaan juga akan meningkat (Husnan dan Pudjiastuti, 2004). Menurut Setiawan (2009) dalam Swandayani dan Kusumaningtias (2012), ROA penting bagi bank karena Bank Indonesia memprioritaskan nilai profitabilitas bank yang dihitung dengan aset yang sebagaian besar dananya berasal dari simpanan masyarakat. Faktor penentu profitabilitas bisa dilihat dari kecukupan modal, efisiensi operasional, likuditas, dan ukuran aset. Karena faktor internal menjelaskan situasi bank dan kinerja bank selama menjalankan aktifitasnya sebagai lembaga intermediasi (Prasanjaya dan Ramantha, 2013).

Tingkat efisiensi bank memengaruhi kuat atau lemahnya suatu bank. Beban Operasional pada Pendapatan Operasional (BOPO) dapat berpengaruh besar dalam mengukur efisiensi dan juga kemampuan bank dalam menjalankan kegiatan operasionalnya. Semakin rendah nilai BOPO, maka semakin efisien bank dalam menjalankan aktivitas usahanya. Dalam perbankan kegiatan utamanya ialah sebagai perantara dalam menghimpun dan menyalurkan dana masyarakat, jadi biaya dan 
ISSN: 2302-8556

E-Jurnal Akuntansi Universitas Udayana Vol.24.2.Agustus (2018): 1164-1189

pendapatan operasional bank didominasi dari biaya bunga dan hasil bunga (Dewi, dkk., 2015). Beberapa penelitian terdahulu yang meneliti tentang pengaruh BOPO tehadap ROA diantaranya penelitian Sinung, dkk., (2016), Victoria dan Erawati (2015), serta (Buchory, 2016) yang menyatakan BOPO berpengaruh negatif signifikan terhadap ROA. Sedangkan hasil penelitian yang berbeda diperoleh oleh (Zulfikar, 2014) dimana BOPO berpengaruh positif dan signifikan terhadap ROA.

Menurut Yasa dan Jati (2013) pemberian kredit adalah salah satu produk andalan bagi bank dimana besaran kredit yang dapat disalurkan oleh bank dapat dijadikan sebagai pendapatan yang diperoleh dari pembayaran bunga kredit yang dapat dijadikan tambahan modal. Sedangkan bagi masyarakat kredit dapat menjadi sebuah tambahan modal usaha ataupun investasi. Dari tugas-tugas yang dijalankan oleh lembaga perbankan, salah satu tujuan utamanya adalah mencari keuntungan atau mencapai tingkat profitabilitas yang maksimal. Penyaluran kredit memiliki peranan penting dalam tingkat profitabilitas yang diperoleh bank karena sumber pendapatan terbesar bank berasal dari penyaluran kredit. Rasio keuangan yang dapat digunakan untuk mengukur penyaluran kredit adalah dengan rasio LDR yaitu rasio antara besarnya volume kredit yang disalurkan oleh bank dan jumlah penerimaan dana dari berbagai sumber. Salah satu fungsi dari LDR adalah sebagai indikator penilaian kesehatan bank. Penelitian terdahulu yang meneliti tentang pengaruh LDR terhadap ROA yang di antara penelitian dari Dewi, dkk., (2015), Wayan dan Putri (2015), serta Eng (2013) yang menyatakan bahwa LDR berpengaruh signifikan terhadap ROA. 
Menyalurkan kredit bank juga harus memperhatikan risiko kredit yang dapat dialami bank seperti tunggakaan pembayaran dari nasabah. Risiko kredit merupakan suatu risiko akibat kegagalan atau ketidakmampuan nasabah dalam mengembalikan jumlah pinjaman yang diterima beserta bunganya, sesuai jangka waktu yang telah ditentukan. Menurut Alexandri dan Santoso (2015), tidak semua pinjaman yang disalurkan oleh bank bebas dari risiko, beberapa di antaranya memiliki risiko yang cukup besar dan dapat mengancam kesehatan bank.

Kredit bermasalah mengacu pada aset keuangan dimana bank tidak lagi menerima bunga atau pembayaran cicilan sesuai jadwal (Lata, 2015). Risiko ini besar apabila bank tidak dapat meningkatkan atau memperbaiki kualitas kredit yang disalurkan, karena pada dasarnya bank menanamkan dananya dalam bentuk kredit dengan harapan dapat meningkatkan profitabilitas. Rasio keuangan yang dapat mengukur risiko kredit yang akan dialami oleh bank adalah rasio NPL. Non Performing Loan (NPL) atau yang sering dikenal dengan kredit bermasalah terjadi karena kurangnya kesadaran dari debitur dalam pengembalian kredit yang sudah disalurkan dan dapat mengancam terjadinya likiuditas terhadap bank tersebut. NPL yang tinggi akan memperbesar biaya, sehingga berpotensi terhadap kerugian bank. Penelitian yang dilakukan oleh Anggreni dan Suardhika (2014), Atmaja dan Sujana (2014), Yanti dan Suryantini (2015), serta Menicucci and Paolucci (2016) menemukan NPL berpengaruh negatif terhadap ROA. Sedangkan, penelitian yang dilakukan oleh Dewi, dkk. (2015) memperoleh perbedaan hasil dimana NPL berpengaruh terhadap ROA. 
ISSN: 2302-8556

E-Jurnal Akuntansi Universitas Udayana

Vol.24.2.Agustus (2018): 1164-1189

Pertumbuhan perbankan baik pemerintah maupun swasta mengalami peningkatan setiap tahunnya. Hal ini menandakan semakin kompetitifnya persaingan antar bank.

Tabel 1.

Perbankan yang Terdaftar di BEI

\begin{tabular}{cc}
\hline Tahun & Jumlah Perbankan \\
\hline 2014 & 39 \\
2015 & 40 \\
2016 & 43 \\
\hline
\end{tabular}

Sumber: Bursa Efek indonesia, 2018

Pada Tabel 1. dapat dilihat bahwa perbankan yang terdaftar di BEI dari tahun 2014-2016 mengalami peningkatan. Peningkatan ini mengharuskan bank untuk lebih meningkatkan profitabilitasnya dan dapat bersaing dalam mendapatkan investor maupun nasabah yang akan menanamkan kelebihan uangnya untuk dijadikan tambahan modal bagi bank. Alasan pemilihan subjek pada perbankan karena saat ini perbankan fokus pada pencapaian penyaluran kredit, dana pihak ketiga, dan pelayanan lainnya dimana tujuan tersebut adalah untuk meningkatkan aset dan pencapaiaan laba yang maksimal. Namun kenyataannya, besarnya ROA pada Bank Pemerintah dan Bank Umum Swasta tahun 2014-2016 mengalami ketidakstabilan yang cenderung menurun. Berdasarkan latar belakang di atas yang ditunjang oleh hasil-hasil penelitian yang inkonsisten, maka peneliti termotivasi untuk menguji tingkat efisiensi, risiko kredit, tingkat penyaluran kredit pada profitabilitas studi empiris pada perusahaan sektor perbankan swasta yang terdaftar di Bursa Efek Indonesia (BEI) tahun 20142016. 
Berdasarkan paparan tersebut, adapun rumusan masalah dalam penelitian ini adalah: 1) Apakah tingkat efisiensi berpengaruh terhadap profitabilitas bank? 2) Apakah risiko kredit berpengaruh terhadap profitabillitas bank? 3) Apakah tingkat penyaluran kredit berpengaruh terhadap profitabilitas bank?

Penelitian ini diharapkan mampu memberikan manfaat, baik secara teoritis maupun paraktis. Secara teoritis, Penelitian ini dapat memberikan kontribusi dalam bidang akuntansi khususnya mengenai hal yang harus dilakukan untuk meningkatkan profitabilitas serta menambah pengetahuan mengenai bagaimana tata kelola perusahaan yang baik. Penelitian ini juga bertujuan untuk membuktikan bagaimana teori regulasi dapat mengatur aturan-aturan atau ketentuan dalam akuntansi. Secara praktis, Hasil penelitian ini dapat memberikan informasi kepada investor untuk membantu pengambilan keputusan dalam melakukan investasi. Penelitian ini juga diharapkan dapat menjadi referensi bagi perusahaan agar dapat lebih meningkatkan profitabilitasnya. Serta penelitian ini juga diharapkan mampu memberikan informasi yang relevan dan memperkuat penelitian sebelumnya mengenai profitabilitas.

Menurut Stigler (1971) dalam Saputra dan Budiasih (2016), sebagai pengembang teori ekonomi regulasi (economi theory of regulation), regulasi merupakan tindakan penekanan kelompok yang menghasilkan hukum dan kalangan bisnis serta melindungi konsumen, pekerja, dan lingkungan. Regulasi perbankan di Indonesia secara umum diterapkan dalam peraturan Bank Indonesia melalui surat edarannya yang selalu diperbarui atau diubah sesuai dengan kondisi dan situasi perbankan nasional (Saputra dan Budiasih, 2016). Peran regulasi dalam industri 
ISSN: 2302-8556

E-Jurnal Akuntansi Universitas Udayana

Vol.24.2.Agustus (2018): 1164-1189

perbankan adalah melakukan kebijakan pengaturan dan pengawasan untuk mewujudkan stabilitas ekonomi nasional (Yusuf, 2009 dalam Saputra dan Budiasih, 2016).

BOPO adalah rasio antara beban operasional pada pendapatan operasional. Beban operasional digunakan untuk mengukur tingkat efisien dan kemampuan bank dalam melakukan kegiatan operasional. Bank yang efisien adalah bank yang mampu menekan biaya operasionalnya sehingga dapat mengurangi kerugian akibat ketidakefisienan bank dalam mengelola usahanya dan keuntungan yang didapatkan akan meningkat. Semakin rendah nilai BOPO menggambarkan semakin efisien bank dalam menjalankan kegiatan usahanya sehingga semakin sehat bank tersebut. Menurut Bank Indonesia, efisiensi operasional dinilai dengan membandingkan jumlah beban operasional dengan jumlah pendapatan operasional (BOPO). Maka dapat dikatakan bahwa variabel efisiensi operasional yang diproksikan oleh BOPO berpengaruh negatif pada ROA. Penelitian tersebut sejalan dengan penelitian yang dilakukan oleh Saputra dan Budiasih (2016), Victoria dan Erawati (2015) yang mendapatkan hasil bahwa jika BOPO semakin meningkat berarti biaya operasional bank semakin besar, sehingga mengakibatkan laba semakin menurun, pada akhirnya akan mengakibatkan profitabilitas bank menurun (Dito, 2011 dalam Saputra dan Budiasih, 2016). Berdasarkan teori dan penelitian sebelumnya, maka rumusan hipotesisnya sebagai berikut.

$\mathrm{H}_{1}$ : $\quad$ Semakin rendah beban operasional dibandingkan pendapatan operasional maka semakin tinggi profitabilitas. 
Rasio NPL menggambarkan keefisiensian manajemen bank untuk mengelola kredit bermasalah yang diberikan oleh bank. Semakin tinggi rasio NPL maka semakin buruk kualitas kredit yang menyebabkan jumlah kredit bermasalah semakin besar sehingga dapat menyebabkan kemungkinan suatu bank dalam kondisi bermasalah semakin besar. Maka, semakin besar rasio NPL semakin rendah profitabilitas bank. Semakin besar NPL, mengakibatkan menurunnya ROA yang berarti kinerja keuangan bank yang menurun. Sebaliknya, jika NPL turun maka ROA dapat meningkat dan profit keuangan bank semakin baik, sehingga dapat dirumuskan hipotesis bahwa NPL berpengaruh negatif terhadap ROA. Penelitian tersebut sejalan dengan penelitian yang dilakukan oleh Prima dan Sujana (2015), Anggreni dan Suardhika (2014), dan (Negara dan Sujana, 2014). Berdasarkan teori dan penelitian sebelumnya, maka dapat dirumuskan hipotesis kedua yakni sebagai berikut

$\mathrm{H}_{2}$ : $\quad$ Semakin rendah tingkat kredit bermasalah dibandingkan total kredit maka semakin tinggi profitabilitas.

Loan to Deposit Ratio (LDR) dapat menggambarkan bagaimana ketrampilan perbank dapat menyediakan dana bagi debiturnya yang berasal dari modal yang dimiliki oleh bank maupun dana yang didapat dari masyarakat. Loan to Deposit Ratio (LDR) mencerminkan kemampuan bank dalam membayar kembali penarikan dana yang dilakukan deposan dengan mengandalkan kredit yang diberikan sebagai sumber likuiditasnya. Semakin tinggi nilai rasio LDR menunjukkan semakin rendahnya kemampuan likuiditas bank yang bersangkutan sehingga kemungkinan suatu bank 
ISSN: 2302-8556

E-Jurnal Akuntansi Universitas Udayana Vol.24.2.Agustus (2018): 1164-1189

dalam kondisi bermasalah akan semakin besar (Lesmana, 2008 dalam Arifianto, 2016). LDR yang dimaksudkan adalah yang tidak melebihi dari batas yang telah ditentukan, maka akan menaikkan profitabilitas yang berasal dari pendapatan bunga kredit sehingga dapat dirumuskan hipotesis bahwa LDR berpengaruh positif terhadap ROA. Penelitian tersebut sejalan dengan penelitian yang dilakukan oleh Victoria dan Erawati (2015), dan Dania dan Sujana (2015). menunjukkan Loan to Deposit Ratio (LDR) berpengaruh positif pada Return on Assets (ROA). Berdasarkan teori dan penelitian sebelumnya, maka dapat dirumuskan hipotesis ketiga yakni sebagai berikut:

$\mathrm{H}_{3}$ : $\quad$ Semakin tinggi jumlah kredit yang di salurkan dibandingkan dana pihak ketiga maka semakin tinggi profitabilitas.

\section{METODE PENELITIAN}

Desain penelitian yang digunakan dalam penelitian ini adalah pendekatan kuantitatif yang berbentuk asosiatif. Menurut Sugiyono (2017:8), metode penelitian kuantitatif adalah metode penelitian yang digunakan untuk meneliti populasi atau sampel tertentu yang bertujuan untuk menguji hipotesis yang telah ditetapkan dengan menggunakan data yang telah dikumpulkan. Asosiatif yaitu penelitian yang bertujuan untuk mengetahui hubungan antara dua variabel atau lebih (Sugiyono,2017:6).

Lokasi penelitian ini pada perusahaan perbankan swasta yang terdaftar pada Bursa Efek Indonesia (BEI) pada tahun 2014-2016 melalui situs www.idx.co.id. Obyek penelitian adalah suatu atribut atau nilai orang, obyek atau kegiatan yang mempunyai variasi tertentu yang diterapkan oleh peneliti untuk dipelajari dan 
kemudian memperoleh kesimpulannya (Sugiyono, 2017:28). Obyek pada penelitian ini adalah profitabilitas pada sektor perbankan swasta yang terdaftar di Bursa Efek Indonesia (BEI) tahun 2014-2016.

Variabel bebas dalam penelitian ini adalah Tingkat Efisiensi $\left(\mathrm{X}_{1}\right)$, Risiko Kredit (X2), dan Tingkat Penyaluran Kredit (X3). Tingkat efisiensi $\left(\mathrm{X}_{1}\right)$ yang diukur dengan BOPO merupakan rasio yang menunjukkan bahwa semakin rendah nilai BOPO, maka semakin efisien bank dalam menjalankan aktivitas usahanya (Lestari dan Suartana, 2017). Biaya operasional pada bank adalah seluruh biaya yang dikeluarkan oleh bank yang meliputi biaya gaji, biaya pemasaran, biaya bunga. Sedangkan untuk pendapatan pada bank adalah pendapatan yang diterima oleh bank melalui penyaluran kredit dalam bentuk suku bunga. Risiko kredit (X2) merupakan kredit macet atau kredit bermasalah pada bank. Risiko kredit dapat diukur dengan NPL, menunjukkan jika semakin kecil NPL maka semakin kecil pula risko yang ditanggung oleh pihak bank (Anggreni dan Suardhika, 2014). Loan to Deposits Ratio (LDR) (X3) adalah rasio yang menunjukkan tingkat kemampuan bank dalam menyalurkan dana pihak ketiga. LDR ini dimaksudkan untuk mengukur kemampuan bank dalam memenuhi pembayaran kembali kredit yang disalurkan oleh kreditur dapat dikembalikan kembali sebelum jatuh tempo oleh debitur. Variabel dependen/terikat dalam penelitian ini adalah Profitabilitas (Y). Menurut Seiford dan Zhu (1999), menyatakan bahwa profitabilitas merupakan kemampuan bank untuk mendapatkan revenue atau profit pada jangka waktu tertentu dengan menggunakan tenaga kerja, asset dan modal. Salah satu rasio yang dipergunakan oleh bank untuk mengukur tingkat 
ISSN: 2302-8556

E-Jurnal Akuntansi Universitas Udayana

Vol.24.2.Agustus (2018): 1164-1189

profitabilitas adalah ROA. ROA mencerminkan kemampuan manajemen bank dalam seberapa efektif suatu bank dalam mengelola asetnya untuk menghasilkan suatu keuntungan dalam menghasilkan laba.

Populasi dalam penelitian ini adalah seluruh perusahaan perbankan swasta yang terdaftar di Bursa Efek Indonesia dari tahun 2014-2016 yang dapat diakses melaui www.idx.co.id. Bank Swasta dipilih sebagai populasi karena pertumbuhan Bank Swasta di Indonesia sangat banyak yang mengakibatkan adanya persaingan yang sengit antar bank terutama untuk mendapatkan investor dan nasabah. Sehingga penting bagi bank swasta baik asing maupun nasional untuk terus meningkatkan profitabilitasnya. Pemilihan sample penelitian diambil dari populasi tersebut berdasarkan pendekatan nonprobabilitas menggunakan metode purposive sampling. Purposive sampling merupakan metode penentuan sampel dengan pertimbangan tertentu, dimana anggota sampel akan dipilih sedemikian rupa sehingga sampel yang dibentuk tersebut dapat mewakili sifat-sifat populasi (Sugiyono, 2017). Kriteriakriteria yang digunakan adalah: 1) Perusahaan yang termasuk dalam kategori subsektor perbankan swasta yang terdaftar di Bursa Efek Indonesia tahun 2014 sampai dengan tahun 2016. 2) Perbankan yang menyajikan data secara lengkap mengenai variabel yang akan digunakan dalam penelitian ini, yaitu data untuk menghitung BOPO, NPL, LDR, ROA. 
Alat analisis yang digunakan adalah teknik analisis regresi berganda, karena analisis regresi digunakan untuk meneliti pengaruh variabel bebas pada variabel terikat serta menunjukkan arah hubungan variabel-variabel tersebut. Berdasarkan pembahasan teori, data penelitian, variabel-variabel penelitian, dan penelitian terdahulu maka bentuk persamaan regresi berganda penelitian ini menggunakan model sebagai berikut:

$$
Y=\alpha+\beta 1 . X_{1}+\beta 2 . X_{2}+\beta 3 . X_{3}+\varepsilon .
$$

Keterangan:

$$
\begin{aligned}
& \text { Y = Profitabilitas } \\
& \alpha=\text { Konstanta } \\
& \beta 1, \beta 2, \beta 3=\text { Koefesien regresi } \\
& \mathrm{x}_{1} \quad=\text { Tingkat Efisiensi } \\
& \mathrm{x}_{2} \quad=\text { Risiko Kredit } \\
& \mathrm{x}_{3} \quad=\text { Tingkat Penyaluran Kredit } \\
& \varepsilon=\text { Error }
\end{aligned}
$$

\section{HASIL DAN PEMBAHASAN}

Statistik deskriptif disajikan untuk memberikan informasi mengenai karakteristik variabel-variabel penelitian yang terdiri dari jumlah amatan, nilai minimum, nilai rata-rata, dan standar deviasi (simpangan baku) dengan $\mathrm{N}$ merupakan banyaknya responden penelitian. Hasil analisis statistik deskriptif dapat dilihat pada Tabel 2.

\section{Tabel 2.}

\section{Hasil Statistik Deskriptif}

\begin{tabular}{lllllc}
\hline Variabel & $\mathbf{N}$ & Min. & Maks. & Rata-rata & Simpangan Baku \\
\hline $\mathrm{Y}$ & 114 & -11.55 & 4.00 & 0,761 & 2.390 \\
$\mathrm{X}_{1}$ & 114 & 56.04 & 235.20 & 93.00 & 25.209 \\
$\mathrm{X}_{2}$ & 114 & 0,080 & 5.45 & 1,90 & 1,319 \\
$\mathrm{X}_{3}$ & 114 & -5.20 & 112.54 & 83.141 & 14.951 \\
\hline \multicolumn{5}{l}{ Sumber: } \\
Data diolah, 2018
\end{tabular}


ISSN: 2302-8556

E-Jurnal Akuntansi Universitas Udayana Vol.24.2.Agustus (2018): 1164-1189

Pada Tabel 2 Variabel Profitabilitas (Y) yang diukur dengan menggunakan Return On asset (ROA) merupakan perbandingan antara laba tahun berjalan dengan rata-rata aset. Nilai minimum profitabilitas sebesar -11,55 dan maksimum 4.00. perusahaan dengan nilai profitabilitas terendah yang dimiliki oleh Bank Of India Indonesia Tbk. (BSWD) pada tahun 2016, sedangkan perusahaan dengan profitabilitas tertinggi yang dimiliki oleh Bank Central Asia Tbk. (BBCA) pada tahun 2016. Rata-rata (mean) untuk profitabilitas adalah sebesar 0,7610. Nilai rata-rata profitabilitas lebih mendekati nilai maksimum. Hal ini berarti rata-rata profitabilitas perusahaan perbankan swasta cemderung tinggi. Simpangan baku (standar deviasi) untuk profitabilitas sebesar 2,390. Simpangan baku profitabilitas lebih besar dari pada nilai rata-rata. Hal ini berarti ada fluktuasi tinggi pada profitabilitas perusahaan perbankan swasta yang menjadi sample.

Variabel Tingkat efisiensi $\left(\mathrm{X}_{1}\right)$ yang diukur dengan menggunakan BOPO merupakan perbandingan antara beban operasional dengan pendapatan operasional. Nilai minimum tingkat efisiensi sebesar 56,04 dan maksimum 235,20. Perusahaan dengan nilai tingkat efisiensi terendah yang dimiliki oleh Bank Woori Saudara Indonesia (SDRA) pada tahun 2014, sedangkan perusahaan dengan tingkat efisiensi tertinggi yang dimiliki oleh Bank of India Indonesia Tbk. (BSWD) pada tahun 2016. Rata-rata (mean) untuk tingkat efisiensi adalah sebesar 93,0. Nilai rata-rata tingkat efisiensi lebih mendekati nilai minimum cenderung rendah. Simpangan baku (standar deviasi) untuk tingkat efisiensi sebesar 2,209. Simpangan baku tingkat efisiensi lebih 
kecil dari pada nilai rata-rata. Hal ini berarti ada fluktuasi rendah pada variabel tingkat efisiensi perusahaan perbankan swasta yang menjadi sampel.

Variabel Risiko Kredit $\left(\mathrm{X}_{2}\right)$ yang diukur dengan menggunakan NPL merupakan perbandingan antara kredit yang bermasalah dengan total kredit. Nilai minimum risiko kredit sebesar 0,08 dan maksimum 5,45. Perusahaan dengan nilai risiko kredit terendah yang dimiliki oleh Bank Bumi Arta Tbk. (BNBA) pada tahun 2014 dan Bank Ina Perdana Tbk. (BINA) pada tahun 2015, sedangkan perusahaan dengan risiko kredit tertinggi yang dimiliki oleh Bank JTrust Indonesia Tbk. (BCIC) pada tahun 2014. Rata-rata (mean) untuk risiko kredit adalah sebesar 1,90. Nilai rata-rata risiko kredit lebih mendekati nilai minimum cenderung rendah. Simpangan baku (standar deviasi) untuk risiko kredit sebesar sebesar 1,319. Simpangan baku risiko kredit lebih kecil dari pada nilai rata-rata. Hal ini berarti ada fluktuasi rendah pada variabel risiko kredit perusahaan perbankan swasta yang menjadi sampel.

Variabel Tingkat Penyaluran Kredit $\left(\mathrm{X}_{3}\right)$ yang diukur dengan menggunakan Loan Deposit Rasio (LDR) merupakan perbandingan antara kredit yang disalurkan denga dana pihak ketiga. Nilai minimum tingkat penyaluran kredit sebesar -5,20 dan maksimum 112,54. Perusahaan dengan nilai tingkat penyaluran kredit terendah yang dimiliki oleh Bank Pembangunan Daerah Banten Tbk. (BEKS) pada tahun 2014, sedangkan perusahaan dengan tingkat penyaluran kredit yang tertinggi dimiliki oleh Bank QNB Indonesia Tbk. (BKSW) pada tahun 2015. Rata-rata (mean) untuk tingkat penyaluran kredit adalah sebesar 83,14. Nilai rata-rata risiko tingkat penyaluran kredit lebih mendekati nilai maksimum cenderung tinggi. Simpangan baku (standar 
ISSN: 2302-8556

E-Jurnal Akuntansi Universitas Udayana Vol.24.2.Agustus (2018): 1164-1189

deviasi) untuk risiko kredit sebesar sebesar 14,95. Simpangan baku tingkat penyaluran kredit lebih kecil dari pada nilai rata-rata. Hal ini berarti ada fluktuasi rendah pada variabel tingkat penyaluran kredit perusahaan perbankan swasta yang menjadi sampel.

Analisis data dalam penelitian ini menggunakan metode analisis regresi berganda. Analisis regresi berganda digunakan untuk mengetahui dan menunjukkan arah serta besarnya pengaruh tingkat efisiensi, risiko kredit, tingkat penyaluran kredit baik secara simultan maupun parsial terhadap profitabilitas pada perusahaan perbankan swasta yang terdaftar di BEI tahun 2014-2016. Hasil analisis regresi berganda yang disajikan pada Tabel 3 .

Tabel 3.

Hasil Analisis Regresi Linear Berganda

\begin{tabular}{llrrrrr}
\hline \multicolumn{1}{c}{ Model } & \multicolumn{2}{c}{$\begin{array}{c}\text { Unstandardized } \\
\text { Coefficients }\end{array}$} & \multicolumn{2}{c}{$\begin{array}{c}\text { Standardized } \\
\text { Coefficients }\end{array}$} & T & Sig. \\
& \multicolumn{1}{c}{ B } & Std. Error & \multicolumn{1}{c}{ Beta } & & \\
\hline $1 \quad$ (Constant) & $1.884 \mathrm{E}-15$ & .060 & & .000 & 1.000 \\
& $\mathrm{X}_{1}$ & -0.249 & .076 & -0.249 & -3.268 & 0.001 \\
& $\mathrm{X}_{2}$ & -0.232 & .082 & -0.232 & -2.838 & 0.005 \\
\multicolumn{1}{c}{$\mathrm{X}_{3}$} & & 0.445 & .074 & 0.445 & 5.993 & 0.000 \\
F hitung & $:$ & 53,882 & & & & \\
Signifikansi F & $:$ & 0,000 & & & & \\
R Square & $:$ & 0,595 & & & & \\
Adjusted R Square & $:$ & 0,584 & & & & \\
\hline
\end{tabular}

Sumber: Data diolah, 2018

Koefisien Determinasi pada model regresi linear berganda dilihat dari nilai Adjusted R-Square sebesar 0,584. Hal ini berarti bahwa tingkat efisiensi, risiko kredit, dan tingkat penyaluran kredit berpengaruh signifikan terhadap profitabilitas perbankan swasta yang terdaftar di Bursa Efek Indonesia. Secara bersama-sama, tingkat efisiensi, risiko kredit, dan tingkat penyaluran kredit berpengaruh sebesar 
$58,4 \%$, sedangkan sisanya sebesar 41,60 dapat dipengaruhi oleh variabel lain yang tidak masuk dalam model.

Uji F digunakan untuk melihat kelayakan model penelitian. Berdasarkan model yang telah dianalisis, diketahui $\mathrm{F}_{\text {hitung }}$ sebesar 53,882, signifikansi ( $p$-value) sebesar 0,000. Berdasarkan nilai toleransi yang diberikan yaitu $\alpha=5 \%$ dengan nilai signifikansi $0,000<\alpha(0,05)$, hal ini mengandung arti bahwa seluruh variabel dapat menjelaskan fenomena profitabilitas pada perbankan swasta dan model regresi yang digunakan dianggap layak uji.

Tabel 3 menunjukkan koefisien BOPO terhadap ROA diperoleh nilai Signifikansi sebesar 0,001 dengan nilai koefisien $\left(\beta_{1}\right)-0,249$. Nilai Signifikansi 0,001 $<$ 0,05 mengindikasikan bahwa $\mathrm{H}_{0}$ ditolak dan $\mathrm{H}_{1}$ diterima. Hasil ini mempunyai arti bahwa semakin rendah biaya operasional dibandingkan pendapatan operasional maka semakin tinggi profitabilitas. Berdasarkan hasil penelitian yang telah dilakukan tingkat efisiensi berpengaruh negatif terhadap profitabilitas. Dengan adanya peningkatan efisiensi pada perbankan dapat memberikan pengaruh signifikan negatif pada profitabillitas, sebaliknya apabila tingkat efisiensi menurun maka profitabilitas perbankan akan meningkat. Kondisi ini di sebabkan oleh tingkat efisiensi bank dalam menjalankan operasionalnya, berpengaruh terhadap tingkat pendapatan yang dihasilkan oleh bank tersebut (Sinung dkk, 2016). 
ISSN: 2302-8556

E-Jurnal Akuntansi Universitas Udayana Vol.24.2.Agustus (2018): 1164-1189

Rasio BOPO merupakan rasio perbandingan antara biaya operasional dengan pendapatan operasional (Riyadi, 2006:159). Semakin besar rasio BOPO maka semakin besar biaya pendapatan setiap unit. Sehingga apabila biaya operasional yang dikeluarkan oleh bank tersebut mengalami peningkatan dan berbanding terbalik dengan pendapatan yang diterima oleh bank maka akan mngakibatkan tidak efiensnya bank, dimana yang pada akhirnya akan dapat memperkecil $R O A$ yang dimilik oleh bank tersebut. Hasil penelitian ini sejalan dengan hasil penelitian dari Prasanjaya dan Ramantha (2013), dan Eng (2013) yang menyatakan bahwa BOPO berpengaruh negatif terhadap ROA.

Tabel 3 menunjukkan koefisien NPL terhadap ROA diperoleh nilai Signifikansi sebesar 0,005 dengan nilai koefisien $\left(\beta_{2}\right)-0,232$. Nilai Signifikansi 0,005 $<0,05$ mengindikasikan bahwa $\mathrm{H}_{0}$ ditolak dan $\mathrm{H}_{2}$ diterima. Hal ini berarti semakin rendah tingkat kredit bermasalah dibandingkan total kredit maka semakin tinggi profitabilitas. Berdasarkan hasil penelitian yang telah dilakukan, risiko kredit berpengaruh negatif pada profitabilitas. Semakin tinggi risiko kredit akan mengakibatkan semakin besar biaya, sehingga berpotensi pada kerugian bank (Dewi, dkk, 2015). Menurut Surya dan Sudirman, 2013 penurunan ROA dapat disebabkan oleh meningkatnya pembentukan PPAP semakin menurunnya pendapatan bunga yang diperoleh sehingga dapat mengakibatkan kerugian bagi bank. Maka mengakibatkan menurunnya laba yang dapat diperoleh yang berarti menurunnya profitabilitas atau menurunnya rasio ROA. Hasil penelitian ini sejalan dengan penelitian yang dilakukan oleh Anggreni dan Suardhika (2014), Yanti dan Suryantini (2015), dan 
Agustiningrum (2011) yang menyatakan bahwa NPL berpengaruh negatif terhadap profitabilitas

Pada Tabel 3 dapat dilihat bahwa pengaruh LDR terhadap ROA diperoleh dari nilai signifikansi sebesar 0,000 dengan nilai koefisien $(\beta 3) 0,445$. Nilai signifikansi $0,000<0,05$ mengindikasikan bahwa $\mathrm{H}_{0}$ ditolak dan $\mathrm{H}_{3}$ diterima. Hal ini berarti semakin tinggi jumlah kredit yang disalurkan dibandingkan dana pihak ketiga maka semakin tinggi profitabilitas. Berdasarkan hasil penelitian yang dilakukan, tingkat penyaluran kredit berpengaruh positif pada profitabilitas, yang ini berarti semakin banyak kredit yang dapat disalurkan secara lancar maka dapat meningkatkan profitabilitas. Kredit yang disalurkan dapat dikatakan lancar apabila dalam pengembalian bunga kredit maupun pokok pinjaman tidak mengalami tunggakan. Hal ini dapat menggambarkan bagaimana kinerja bank dalam menyalurkan kredit kepada pihak ketiga berjalan cukup efisien (Prasanjaya dan Ramantha, 2013). Pada lembaga perbankan, kredit yang diberikan oleh bank kepada masyarakat merupakan salah satu bentuk penggunaan dana bank yang paling besar dalam usaha untuk mendapatkan penghasilan (Prawira dan Wisadha, 2010).

Pinjaman kredit merupakan salah satu laba yang didapatkan oleh bank yang diperoleh dari bunga pinjaman (Ekpu dan Paloni, 2016). Semakin banyak kredit yang disalurkan, maka pendapatan bunga yang akan yang diterima oleh bank akan meningkat dengan seiring meningkatnya profitabilitas. Dana yang disalurkan oleh perbankan tersebut didapat dari dana pihak ketiga. Hasil penelitian ini sejalan dengan penelitian yang dilakukan oleh Dania dan Sujana (2015), Dewi dkk. (2015), Dewi 
ISSN: 2302-8556

dan Ratnadi (2018) Pamularsih (2013) dan Angbaso (1997) yang memperoleh hasil bahwa LDR berpengaruh positif terhadap profitabilitas.

Implikasi dari hasil penelitian ini mencakup dua hal, yaitu implikasi teoritis dan praktis. Implikasi teoritis penelitian ini diharapkan dapat memberikan kontribusi mengenai pengaruh tingkat efisiensi, risiko kredit, dan tingkat penyaluran kredit terhadap profitabilitas perbankan. Hasil uji dalam penelitian ini ditemukan bahwa satu dari tiga variabel berpengaruh signifikan pada profitabilitas, dimana variabel tersebut adalah tingkat penyaluran kredit. Dalam penelitian ini teori yang digunakan adalah teori regulasi dimana teori ini menjelaskan bahwa bank memiliki peran melakukan kebijakan pengaturan dan pengawasan dalam penyaluran kredit untuk dapat meningkatkan profitabilitas perbankan. Hasil penelitian yang tidak berpengaruh signifikan kemungkinan disebabkan oleh beberapa faktor. Implikasi praktis penelitian ini memberikan implikasi bagi investor sebagai pertimbangan dan pengetahuan mengenai profitabilitas serta faktor-faktor yang mempengaruhinya. Investor dalam melakukan investasinya dapat memperhatikan LDR (Loan Deposit Ratio) karena hal ini adalah salah satu cerminan dari bagaimana perbankan dalam menyalurkan dananya kepada masyakat.

\section{SIMPULAN}

Berdasarkan hasil penelitian yang diperoleh melalui pengujian statistik serta pembahasan maka dapat disimpulkan bahwa: Tingkat efisiensi berpengaruh negatif pada profitabilitas. Hal ini dapat menunjukkan bahwa semakin tinggi beban 
operasional pada pendapatan operasional dapat menurunkan profitabilitas. Risiko kredit berpengaruh negatif pada profitabilitas. Hal ini dapat menunjukkan bahwa semakin rendah tingkat kredit bermasalah dibandingkan total kredit maka profitabilitas akan semakin tinggi. Tingkat penyaluran kredit berpengaruh positif terhadap profitabilitas. Hal ini dapat menunjukkan bahwa semakin tinggi jumlah kredit yang disalurkan dibandingkan dana pihak ketiga maka profitabilitas akan semakin tinggi.

Berdasarkan hasil penelitian dan simpulan di atas, maka saran yang dapat diberikan adalah bagi pihak bank untuk bisa menekan kelebihan biaya operasional dibandingkan pendapatan operasional yang diterima oleh bank itu sendiri, selain itu juga pihak bank harus lebih berhati-hati dalam memberikan kredit kepada masyarakat karena dari hasil penelitian sudah terbukti bahwa risiko kredit dan tingkat efisiensi sudah mempengaruhi dari pada profitabilitas perbankan. Selain itu penelitian ini hanya menggunakan 3 variabel dalam menganalisa profitabilitas pebankan dan objek penelitian masih terbatas di satu subsektor perbankan saja sehingga diharapkan untuk penelitian selanjutnya agar dapat mengembangkan variabel yang diteliti dengan menambah beberapa variabel lain yang dapat mempengaruhi profitabilitas. Selain itu juga untuk peneliti selanjutnya diharapkan untuk memperluas objek penelitian dengan memperpanjang periode penelitian agar dapat menghasilkan hasil penelitian yang lebih baik dan akurat. 
ISSN: 2302-8556

E-Jurnal Akuntansi Universitas Udayana

Vol.24.2.Agustus (2018): 1164-1189

\section{REFERENSI}

Ekpu, V., \& Paloni, A. (2016). Business lending and bank profitability in the UK. Studies in Economics and Finance, 33(2), 302-319. https://doi.org/10.1108/SEF-04-2015-0097

Angbazo, L, (1997), "Commercial Bank Net Interest Margin, Default Risk, InterestRate Risk, and Off-Balance Sheet Banking," Journal of Banking and Finance, 21, 55-87

Afriyie, H. O., \& Akotey, J. O. 2009. Credit Risk Management and Profitability, 1- 18.

Alexandri, M. B., and Santoso, T. I. 2015. Non Performing Loan: Impact of Internal and External Factor (Evidence in Indonesia). International Journal of Humanities and Social Science Invention, 4(1), 87-91.

Anggreni, M. R., dan Suardhika, I. M. S. 2014. Pengaruh Dana Pihak Ketiga, Kecukupan Modal, Risiko Kredit Dan Suku Bunga Kredit Pada Profitabilitas. E-Jurnal Akuntansi Universita Udayana, 9(1), h:27-37.

Arifianto, A. 2016. Pengaruh Capital Adequacy Ratio (CAR), Non Performing Loan $(N P L)$, Biaya Operasional pada Pendapatan Operasional (BOPO), Loan To Deposit Ratio (LDR) dan Net Interest Margin (NIM) terhadap Profitabilitas Bank Umum Konvensional Yang Terdaftar di Bursa Efek Indonesia. Skripsi. Universitas Negeri Yogyakarta.

Buchory, H. A. 2016.Determinants Of Banking Profitability In Indonesian Regional Development Bank.

Dania, N. L. A. P., dan Sujana, I. K. 2015. Pengaruh Capital Adequacy Ratio, Non Performing Loan, Dan Loan To Deposit Ratio Pada Profitabilitas,E-Jurnal Akuntansi Universitas Udayana,13, 1100-1119.

Dewi, L. E., Herawati, N. T., dan Sulindawati, L. G. E. 2015. Analisis Pengaruh NIM ,BOPO , LDR , DAN NPL terhadap Profitabilitas ( Studi Kasus Pada Bank Umum Swasta Nasional yang Terdaftar Pada Bursa Efek Indonesia Periode 2009-2013 ),E-Jurnal Akuntansi Universita Ganesha, 3(1).

Dewi, N. P. E. N., dan Budiasih, I. G. A. 2013. Kualitas Kredit Sebagai Pemoderasi Pengaruh Tingkat Penyaluran Kreditdan BOPO padaProfitabilitas,E-Jurnal Universitas Udayana, 15(1), h:784-798. 
Dietrich, A., and Wanzenried, G. 2009. What Determines the Profitability of Commercial Banks? New Evidence from Switzerland.

Eng, T. S. 2013. Pengaruh NIM, BOPO, LDR, NPL danCARterhadapROA Bank Internasional Dan Bank Nasional Go Public Periode 2007-2010. Jurnal Dinamika Manajemen Universitas Jambi,1(3), h:198-215.

Ekpu, V., and Paloni, A. (2016). Business lending and bank profitability in the UK. Studies in Economics and Finance, 33(2), pp:302-319. https://doi.org/10.1108/SEF-04-2015-0097

George, D. G. enock, and Ouma, B. O. 2013. Effects of Financial Risks on Profitability of Sugar Firms in Kenya, 5(3), pp:152-160.

Ghozali, Imam. 2013. Aplikasi Analisis Multivariate Dengan Program SPSS. Edisi Ketujuh. Semarang: Badan Penerbit Universita Diponegoro.

Islam, M. A., Sarker, Islam Md. Nazirul Rahman, M., andProdhan, A. S. 2013. Determinants of profitability of commercial banks in Bangladesh: International Journal of Economic and Management Sciences, 2(11), pp:108142.

Lata, R. S. 2015. Non-Performing Loan and Profitability: The Case of State Owned Commercial Banks in Bangladesh,World Review of Business Research,5(3), pp:171-182.

Lestari, I. G. agung O. S. I., dan Suartana, I. W. 2017. Pengaruh Tingkat Efisiensi, Risiko Kredit, dan Tingkat Penyaluran Kredit pada Profitabilitas Lembaga Perkreditan Desa (LPD),E-Jurnal Akuntansi Universitas Udayana,19(2), h:1661-1690.

Ekpu, V., \& Paloni, A. (2016). Business lending and bank profitability in the UK. Studies in Economics and Finance, 33(2), 302-319. https://doi.org/10.1108/SEF-04-2015-0097

Menicucci, E., and Paolucci, G. (2016).The determinants of bank profitability: empirical evidence from European banking sector.Journal of Financial Reporting and Accounting 14(1), pp:86-115. https://doi.org/10.1108/JFRA-05$\underline{2015-0060}$

Negara ,A. I. P. A., dan Sujana, I. K. 2014. Pengaruh Capital Adequacy Ratio, Penyaluran Kredit dan Non Performing Loan pada Profitabilitas. E-Jurnal Akuntansi Universitas Udayana, 9(2), h:325-339. 
ISSN: 2302-8556

E-Jurnal Akuntansi Universitas Udayana Vol.24.2.Agustus (2018): 1164-1189

Olalekan, A., and Adeyinka, S. 2013. Capital Adequacy and Banks' Profitability: an Empirical Evidence From Nigeria. American International Journal of Contemporary Research, 3(10), 87-93.

Prasanjaya, A.A. Y., dan Ramantha, I. W. 2013. Analisis Pengaruh Rasio CAR,BOPO, LDR dan Ukuran Perusahaan terhadap Profitabilitas Bank Yang Terdaftar Di BEI. Jurnal Akuntansi Universitas Udayana, 4(1), 2302-8556.

Prastiyaningtyas, F. (2010). Faktor-Faktor Yang Mempengaruhi Profitabilitas Perbankan (Studi pada Bank Umum Go Public Yang Listed di Bursa Efek Indonesia Tahun 2005- 2008), 11(1), h:57-64.

Riyadi, Slamet. 2006. Banking Asset and Liability Management. Jakarta: Fakultas Ekonomi Universitas Indonesia.

Saputra, I. M. B., \& Budiasih, I. G. A. N. (2016). Pengaruh Kecukupan Modal, Risiko Kredit, Biaya Operasional Pendapatan Operasional Pada Profitabilitas Bank. E-Jurnal Akuntansi Universitas Udayana, 14(3), h:230-245.

Sinung, D. K. ., Wardiningsih, S. S., dan Wibowo, E. 2016. Analisis Pengaruh NIM, BOPO, LDR dan NPL terhadapProfitabilitaspada BANK Pemerintahdan BANK Umum Swasta Nasional di Bursa Efek Indonesia, Jurnal Ekonomi dan Kewirausahaan, 16(1), h:30-40.

Swandayani, D. M., dan Kusumaningtias, R. 2012. Pengaruh Inflasi, Suku Bunga, Nilai Tukar Valas dan Jumlah Uang Beredar Terhadap Profitabilitas pada Perbankan Syariah di Indonesia Periode 2005-2009. Jurnal Akuntansi Universitas Negeri surabaya, 3(2), h:147- 166.

Sugiyono. 2017. Metode Penelitian Kuantitatif. dan Kombinasi (Mixed Methods). Bandung: Alfabeta.

Suardita, I. W., dan Putri, I. G. A. M. A. D. 2015. Pengaruh Kecukupan Modal dan Penyaluran Kredit pada Profitabilitas dengan Pemoderasi Risiko Kredit, EJurnal Akuntansi Universitas Udayana, 11(2), h:426-440.Kondisi ekonomi yang buruk dapat memperburuk kualitas portofolio pinjaman,

Seiford, Lawrence M., Zhu, Joe, 1999, "Profitability and Marketability of the top 55 US Commercial Banks", Management Science, vol.45, No.9,September.

Ugo, A., and Gambacorta, L. 2002. Bank Profitability and the business cycle. October, 35(442), pp:1-28. https://doi.org/10.1162/JEEA.2008.6.6.1109 
Victoria, N. P. L., dan Erawati, N. M. 2015. Pengaruh Rasio Keuangan Dan Non Keuangan Pada Kinerja Keuangan Perbankan,E-Jurnal Fakultas Ekonomi Universitas Udayana,13(2), h:625-642.

Yanti, F. A. K., dan Suryantini, N. P. S. 2015.Pengaruh Dana Pihak Ketiga, Kecukupan Modal, Risiko Kredit dan Likuiditas terhadap Profitabilitas LPD Kabupaten Badung,E-Jurnal Manajemen Universita Udayana,4(12), h:83-91.

Yasa, I. D. P. G., \& Jati, I. K. (2013). Pengaruh Komponen Pengendalian Internal Kredit pada Kredit Bermasalah BPR di kabupaten Buleleng, 4(2), h:315-331.

Zulfikar, T. 2014. Pengaruh CAR, LDR, NPL, BOPO dan NIM terhadap Kinerja Profitabilitas (ROA) Bank Perkreditan Rakyat di Indonesia. E-Journal Graduate Unpar, 1(2), h:131-140. Retrieved from http://journal.unpar.ac.id/index.php/unpargraduate/article/view/850 